\title{
Pelatihan Keterampilan Pemanfaatan Limbah Botol Plastik Menjadi Lavitrap Di Kelurahan Sidomulyo Timur Kecamatan Marpoyan Damai Pekanbaru
}

\author{
MURNAWATI ${ }^{1}$; LILI ERTI ${ }^{2}$; AZNURIYANDI ${ }^{3}$ \\ ${ }^{1,2,3}$ Universitas Lancang Kuning \\ Jln. Yos Sudarso KM 08 Rumbai Telp. (0761) 52581 \\ E-mail : $\underline{\text { lili3rti@gmail.com }}$
}

\begin{abstract}
Community service activities carried out by the method of delivery of knowledge through counseling and practice. Community service activities are carried out with the method of delivering knowledge about the science of home industry, counseling and delivery of information about home industry, banana and its benefits, and the way of making lavitrap, counseling and delivery as well as the practice of making lavitrap.
\end{abstract}

Keywords: Economic Improvement And Lavitrap.

Limbah plastik merupakan salah satu penyebab terjadinya kerusakan lingkungan yang berasal dari pola hidup modern saat ini. Limbah ini dari waktu ke waktu mengalami pertambahan jumlah secara signifikan sehingga perlu diupayakan cara pemanfaatannya melalui pengolahan limbah. Botol kemasan minuman terbuat dari material plastik yang mempunyai ketahanan yang cukup tinggi, sehingga tidak mudah hancur. Tidak terkecuali di Kelurahan Sidomulyo Timur Kecamatan Marpoyan Damai Pekanbaru.

Letaknya yang strategis di kota Pekanbaru, dan merupakan pusat perkantoran dan perumahan masyarakat, membuat kelurahan ini menjadi salah satu penyumbang limbah rumah domestik. Sehingga diperlukan penanganan untuk limbah botol plastik ini. Pengelolaan dari sampah anorganik yang dapat dilakukan adalah pencegahan dan pengurangan sampah dari sumbernya serta pemanfaatan kembali sampah baik secara langsung maupun tidak langsung.

Salah satu pengelolaan limbah botol plastic ini adalah memanfaatkan kembali menjadi bahan atau peralatan yang bermanfaat, salah satunya adalah dengan membuat botol plastic bekas menjadi lavitrap. Pembuatan lavitrap ini bertujuan untuk membunuh bibit-bibit nyamuk berupa larva yang nantinya akan jadi nyamuk besar dan beresiko dalam penyebaran penyakit.

Metode penggunaan lavitrap ini adalah untuk menarik perhatian nyamuk agar bertelur di dalamnya. Kemudian telur akan berubah menjadi jentik atau larva nyamuk dan terperangkap di dalamnya. Meski tidak membunuh nyamuk dewasa, karena sudah banyak cara untuk membunuh nyamuk dewasa (dengan menggunakan insektisida), namun lavitrap lebih bertujuan untuk menekan perkembangbiakan nyamuk dengan memerangkap larva dan membunuhnya.

Dengan dimanfaatkannya limbah botol plastic menjadi lavitrap, maka masyarakat mendapatkan manfaat ganda dari kegiatan ini, yaitu berkurangnya limbah botol plastic dan mengurangi pertumbuhan nyamuk di wilayah Kelurahan Sidomulyo Timur Kecamatan Marpoyan Damai Pekanbaru.

Untuk itu kegiatan ini memiliki potensi besar dalam meningkakan ilmu pengetahuan dan kepedulian masyarakat terhadap pengelolaan limbah dan mengurangi pertumbuhan nyamuk sehingga meningkatkan kesehatan masyrakat.

Berdasarkan analisis situasi, maka diperlukan pengelolaan terhadap limbah botol plastic menjadi bahan dan 
alat-alat yang berguna dan bermanfaat. Botol kemasan minuman terbuat dari material plastik yang mempunyai ketahanan yang cukup tinggi, sehingga tidak mudah hancur. Oleh karena itu pemanfaatannya sebagai benda bernilai guna juga akan menghasilkan produk yang tidak mudah hancur dan menjadi lebihbermanfaat bagi lingkungan alam dan sosial. Pada umumnya limbah botol plastik tersebut terbuang dalam bentuk utuh dan menjadi limbah yang dapat dimanfaatkan untuk penggunaan yang lebih luas.

Dampak negatif yang dapat ditimbulkan oleh volume sampah yang tinggi dan tidak terkelola dengan baik adalah gangguan kesehatan, menurunkan kualitas lingkungan, dan menurunkan estetika lingkungan. Sampah plastik merupakan sampah anorganik yang tidak dapat diuraikan oleh alam. Pengelolaan dari sampah anorganik yang dapat dilakukan adalah pencegahan dan pengurangan sampah dari sumbernya serta pemanfaatan kembali sampah baik secara langsung maupun tidak langsung.

Pemanfaatan limbah plastik dari botol minuman membutuhkan kreativitas pelakunya. Keterampilan mengolah limbah ini merupakan pelatihan dasar, yang dapat dikembangkan menjadi aneka bentuk produk lain sesuai dengan kebutuhan pengguna dan kreativitas pembuatnya. Kreativitas merupakan potensi yang terdapat dalam diri setiap orang yang sering kali membutuhkan dukungan keterampilan khusus dalam penerapannya.

Salah satu pengelolaan limbah botol plastic ini adalah dengan membuat lavitrap. Pembuatan lavitrap ini bertujuan untuk membunuh bibit-bibit nyamuk berupa larva yang nantinya akan jadi nyamuk besar dan beresiko dalam penyebaran penyakit. Metode penggunaan lavitrap ini adalah untuk menarik perhatian nyamuk agar bertelur di dalamnya. Kemudian telur akan berubah menjadi jentik atau larva nyamuk dan terperangkap di dalamnya.
Untuk memanfaatkan kembali limbah botol plastic ini, dibutuhkan pengetahuan dan keterampilan bagi masyarakat. Oleh karena itu tujuan dari kegiatan ini adalah mengajak dan memotivasi masyarakat di Kelurahan Sidomulyo Timur, untuk memanfaatkan kembali limbah botol plastic menjadi lavitrap

\section{METODE}

Metode yang digunakan dalam pengabdian pada masyarakat ini adalah :

a. Penyuluhan

Penyuluhan merupakan cara yang paling baik untuk memberikan pengetahuan kepada masyarakat .Pelaksanaan kegiatan mencakup penyediaan materi yang berkaitan dengan :

- Pemberian informasi tentang manfaat lavitrap kepada masyarakat secara keseluruhan.

- Penjelasan bagaimana tahap pelaksanaan proses pembuatan lavitrap

- Memperkenalkan manfaat dari lavitrap.

- Pembagian materi pengabdian ini dilakukan sebelum penyuluhan dimulai, sehingga diharapkan hasil penyuluhan yang maksimal nantinya.

b. Pelatihan dan Percontohan

Pada kegiatan ini akan diperagakan atau didemonstrasikan bagaimana proses pembuatan lavitrap. Kegiatan peragaan dilanjutkan dengan pelatihan pada masyarakat.

c. Diskusi dan Konsultasi

Pada saat penyuluhan, pelatihan atau percontohan dan pembinaan dilakukan diskusi-diskusi dan konsultasi antara pelaksanaan kegiatan dengan masyarakat tentang pelaksanaan teknologi yang diterapkan dan kendala yang dihadapi, untuk lebih memantapkan hasil kegiatan pengabdian kepada masyarakat ini 


\section{d. Evaluasi}

Evaluasi kegiatan ini dilakukan dengan penyebaran kuisioner, sehingga dapat diketahui tingkat pemahaman peserta pada kegiatan pengabdian kepada masyarakat ini.

\section{HASIL}

masyarakat

Hasil wawancara dengan

setempat dan peserta pelatihan, pisang ini pada umumnya dijual langsung ke pasar tanpa diolah menjadi keripik pisang atau bahan olahan makanan lainnya. Adapun hasil kuisioner yang telah diisi oleh peserta kegiatan pengabdian masyarakat, seperti pada tabel berikut ini:

Tabel 1. Hasil Kuesioner Kegiatan Pengabdian kepada Masyarakat

\begin{tabular}{|r|l|c|c|c|}
\hline \multirow{2}{*}{$\mathbf{N}$} & \multicolumn{1}{|c|}{ Komponen } & \multicolumn{3}{|c|}{ Alternatif.Jawaban } \\
\cline { 2 - 5 } & \multicolumn{1}{|c|}{$\mathbf{T}$} & $\mathbf{N}$ & $\mathbf{Y}$ \\
\hline 1. & $\begin{array}{l}\text { Pengetahuan } \\
\text { mengenai } \\
\text { kewirausahaan }\end{array}$ & $40 \%$ & - & $60 \%$ \\
\hline 2. & $\begin{array}{l}\text { Pengetahuan } \\
\text { cara pembuatan }\end{array}$ & $90 \%$ & - & $10 \%$ \\
\hline 3. & Praktek & - & - & 100 \\
\hline 4. & $\begin{array}{l}\text { Pengetahuan } \\
\text { narasumber/ }\end{array}$ & - & - & 100 \\
\hline 5. & $\begin{array}{l}\text { Minat } \\
\text { peserta } \\
\text { untuk } \\
\text { mengembangkan }\end{array}$ & $10 \%$ & 15 & $75 \%$ \\
$\%$ & & \\
\hline
\end{tabular}

Ket: $\mathrm{T}=$ Tidak, $\mathrm{N}=$ Netral, $\mathrm{Y}=\mathrm{Ya}$

Sumber: Data Olahan, 2018

Dari rekapitulasi kuisioner diatas maka dapat diketahui bahwa terjadi peningkatan pengetahuan peserta kegiatan mengenai kewirausahaan dan peluang usaha mandiri meningkat dimana peserta yang pada awalnya hanya $60 \%$ saja yang mengetahui menjadi $100 \%$ mengetahui dan memahami mengenai kewirausahaan. Sedangkan pengetahuan mengenai pembuatan lavitrap meningkat menjadi $100 \%$, dari awalnya hanya $10 \%$ saja yang mengetahuinya. Sedangkan $100 \%$ peserta mengetahui dan memahami proses pembuatan lavitrap melalui praktek langsung yang didampingi oleh tim pelaksana kegiatan pengabdian. Dan $75 \%$ peserta kegiatan pengabdian berminat untuk menjadikan lavitrap ini sebagai peluang usaha mandiri.

\section{PEMBAHASAN}

Proses kegiatan pengabdian dilakukan dengan cara demonstrasi dan ceramah, dimana ceramah dilakukan unmtuk menampaikan informasi tentang kewirausahaan dan peluang usaha serta dan cara pembuatan lavitrap. Secara garis besar hasil kegiatan yang telah dicapai dalam pengabdian masyarakat ini adalah sebagai berikut:

1. Materi kegiatan, mengenai kewirausahaan dan peluang usaha serta dan cara pembuatan lavitrap pada umumnya dapat dterima dan dapat dipahami serta mendapat respon dari peserta yang ditandai dengan adanya pertanyaan- pertanyaan yang muncul.

2. Berdasarkan sikap dan pertanyaan yang diajukan dapat diketahui bahwa materi pengabdian sangat membantu dalam peningkatan pengetahuan masyarakat.

3. Dari hasil pengabdian ini diharapkan nantinya akan ada tindak lanjut.

4. Berdasarkan evaluasi dapat diketahui bahwa pada umumnya peserta pengabdian telah memahami tentang kewirausahaan dan peluang usaha serta dan cara pembuatan lavitrap serta manfaatnya dalam meningkatkan perekonomian keluarga.

\section{SIMPULAN}

Kegiatan terlaksana sesuai dengan tujuan dan rencana. Pada penyelenggaraan kegiatan ini dapat diketahui bahwa ada peningkatan pengetahuan peserta mengenai kewirausahaan dan peluang usaha serta dan cara pembuatan lavitrap. Program atau kegiatan ini sangat efektif dalam penerapan ilmu pengetahuan dan teknologi bagi masyarakat. Dengan teknologi yang 
sederhana, pembuatan lavitrap dapat mengurangi limbah botol plastic serta dapat mengurangi berkembangnya nyamuk yang menyebabkan penyakit demam berdarah dan malaria. Selain itu pembuatan lavitrap ini dapat memberikan nilai ekonomis terutama dalam meningkatkan peluang usaha mandiri serta dapat dijadikan sebagai sumber penghasilan dalam rangka meningkatkan penghasilan masyarakat.

Berdasarkan pengamatan yang diperoleh dari kegiatan ini, maka perlu dilanjutkan dengan pembinaan yang berkesinambungan dan memberi pembekalan mengenai teknik pemasaran.

\section{DAFTAR RUJUKAN}

Alfin, Edward. (2015). Pemanfaatan limbah rumah tangga sebagai bentuk implementas dari pendidikan lingkungan hidup Universitas Indraprasta. https://thesains.wordpress.com/2013 /11/19/pemanfaatan-limbah-rumahtangga- sampah-anorganik-sebagaibentuk- implementasi-daripendidikan-lingkungan- hidup/

Bn, (2013). "Produksi Sampah Jakarta mencapai 7,8 Ton per Hari". Diakses 3 Oktober 2017 dari

http://www.ciputranews.com/diskusi - publik/produksi-sampah-jakartamencapai-7-8- ton-per-hari

Herjanto Eddy.(1999). Manajemen Produksi dan operasi. Edisi Kedua. Penerbit PT. Gramedia Widiasarana Indonesia, Jakarta.

Kotler, P. (1997). Manajemen Pemasaran. Diterjemahkan oleh Hendra Teguh dari Buku Marketing Management 9th Ed. Jakarta: Prenhallindo
Soemarwoto, Otto. (2004). Ekologi, Lingkungan Hidup dan Pembangunan, Cetakan Kesepuluh. Jakarta: Penerbit Djambatan.

Tabrani, Primadi. (2006). Kreativitas dan Humanitas. Yogyakarta: Jalasutra. 